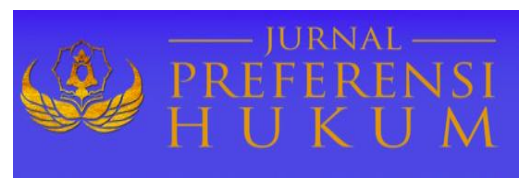

Jurnal Preferensi Hukum | ISSN: XXXX | E-ISSN: XXXX

Vol. 1 No. 1 - Juli 2020 hal. 184-188| Available online at https://www.ejournal.warmadewa.ac.id/index.php/juprehum

\title{
PERLINDUNGAN HUKUM TERHADAP KONSUMEN PARKIR DALAM HAL TERJADI KEHILANGAN DI AREA PARKIR LAPANGAN RENON KOTA DENPASAR
}

\author{
IB. Kade Ari Dwi Putra \\ Fakultas Hukum Universitas Warmadewa, Denpasar-Bali, Indonesia
}

\begin{abstract}
Abstrak
Perlindungan konsumen adalah suatu usaha yang digunakan untuk melindungi konsumen, salah satunya konsumen pengguna jasa parkir sehingga didirikanlah Perusahaan Daerah Parkir. Tujuan penelitian ini adalah untuk mengetahui Penerapan Peraturan Daerah Nomor 11 tahun 2005 tentang Sistem Penyelenggaraan Perparkiran di Kota Denpasar dan upaya Perusahaan Daerah Parkir Kota Denpasar dalam melindungi pengguna jasa parkir terkat kehilangan di area parkir Lapangan Renon Denpasar. Penelitian ini menggunakan metode yuridis empiris dengan pendekatan sosiologis hukum. Metode pengumpulan data yang digunakan dalam penelitian ini adalah metode wawancara dan studi literatur. Data dalam penelitian ini bersumber dari data primer dan sekunder. Hasil penelitian ini yakni masih terdapat tarif parkir yang tidak sesuai ketentuan, masih terdapat petugas parkir yang melakukan pemungutan parkir pada area yang ada larangan parkir dan masih ada petugas yang tidak mau melayani konsumen dengan baik. Upaya perusahaan daerah parkir dalam melindungi konsumen yaitu dengan melakukan kegiatan evaluasi setiap tahun, meningkatkan pelayanan keamanan dengan mengadakan pelatihan juru parkir setiap tahun dan mengimbau konsumen parkir untuk ikut serta menjaga barang bawaannya.
\end{abstract}

Kata Kunci: Konsumen; Parkir; Perlindungan Konsumen; Kehilangan

\begin{abstract}
Abstarct
Consumer protection is an effort that is used to protect consumers, one of which is consumers of parking service consumers, so a Parking Area Company was established. The purpose of this study was to determine the Application of Regional Regulation No. 11 of 2005 concerning Parking Operational Systems in Denpasar City and the efforts of the Denpasar City Parking Area Company in protecting lost parking service users in the parking area of Renon Field in Denpasar. This research uses an empirical juridical method with a sociological approach to law. Data collection methods used in this research are interview and literature study methods. The data in this study were sourced from primary and secondary data. The results of this study are there are still parking rates that do not comply with the provisions, there are still parking officers who collect parking in areas that have parking restrictions and there are still officers who do not want to serve consumers well. The effort of parking area companies in protecting consumers is by conducting evaluation activities every year, improving security services by holding parking attendant training every year and encouraging parking consumers to participate in protecting their luggage.
\end{abstract}

Keywords: Consumer; Parking; Consumer Protection; Loss

\section{PENDAHULUAN}

Perlindungan konsumen adalah suatu usaha yang didalamnya memuat asas, kaidah atau aturan yang digunakan untuk memberikan perlindungan, serta melindungi hak konsumen. Konsumen adalah seseorang atau sesuatu perusahaan yang membeli barang atau menggunakan jasa tertentu (Handayani, 2012). Perlindungan terhadap hak konsumen meliputi atas kenyamanan, keamanan dan keselamatan, informasi yang benar jelas dan jujur mengenai kondisi barang dan jasa serta mendapat advokasi, pembinaan konsumen agar diperlakukan secara benar. Konsumen juga berhak untuk mendapatkan ganti rugi atau penggantian apabila konsumen menerima barang dan jasa tidak sesuai dengan perjanjian yang telah ditentukan dalam peraturan perundang-undangan. 
Dengan ditegakannya hukum perlindungan konsumen, yang merupakan digunakan sebagai tolak ukur karena bagian terpenting yang mampu memberikan kepercayaan kepada masyarakat. Perlindungan hukum merupakan upaya untuk pemenuhan hak dan memberikan rasa aman kepada subyek hukum baik bersifat preventif atau represif secara lisan ataupun tertulis. Pancasila merupakan ideology atau falsafah negara yang dijadikan landasan dalam perumusan prinsip perlindungan hukum.

Parkir merupakan tempat pemberhentian sementara untuk kendaraan pada tempat yang telah ditentukan dan tentunya dikenakan biaya atau retribusi sebagai pembayaran karena telah menggunakan jasa atau fasilitas yang disediakan oleh pemerintah, sedangkan setiap objek parkir yang ada di wilayah pemerintah kota Denpasar yang berada ditepi jalan umum diatur sesuai dengan ketentuan peraturan perundang-undangan. Dalam hal ini pengguna jasa atau konsumen memiliki kewajiban untuk membaca dan mengikuti prosedur pemakaian, petunjuk informasi dan pemanfaatan barang atau jasa, selain itu pengguna jasa atau konsumen juga harus memiliki itikad baik dan membayar sesuai dengan nilai tukar yang telah disepakati, ini merupakan faktor penting yang harus ditaati agar membentuk konsumen atau pengguna jasa parkir yang cerdas demi keselamatan bersama.

Terkait sistem penyelenggaraan perparkiran dalam pengelolaannya pasti terdapat masalah diantaranya terjadi kasus kehilangan baik berupa kendaraan utuh, atribut kendaraan ataupun barang bawaan konsumen yang tertinggal di kendaraan. Senada dengan itu, sangat mungkin terjadinya kehilangan atau kerusakan kendaraan bermotor ketika kendaraan tersebut dititipkan dan berada dalam kekuasaan pelaku usaha (Budhiono, 2015) yang pastinya akan merugikan pemilik kendaraan karena sudah membayar retribusi yang telah ditentukan. Perselisihan juga sering terjadi antara pemilik kendaraan dengan petugas parkir karena atas hilangnya kendaraan baik kendaraan utuh, atribut kendaraan ataupun barang bawaan konsumen yang tertinggal di kendaraan petugas parkir tidak mau disalahkan (Yanto, Imawanto, \& Yuliani, 2020), maka untuk mengatur sistem penyelenggaraan perparkiran didirikanlah perusahaan daerah parkir.

Penelitian dengan permasalahan yang hampir serupa juga pernah dikaji, salah satunya tentang perlindungan hukum terhadap konsumen akibat kehilangan kendaraan dalam area parkir (studi kasus pasar umum Desa Pakraman Sukawati), menunjukkan bahwa pihak Lembaga Pemberdayaan Desa Pakraman (LPDP) mengadakan negosiasi jika kehilangan berasal dari pengguna jasa parkir maka pihak LPDP tidak berkewajiban memberikan ganti rugi dan perlindungan terhadap pengguna jasa parkir, tetapi jika kehilangan berasal dari kesalahan juru parkir maka pihak LPDP wajib mengganti rugi dan memberi perlindungan terhadap pengguna jasa parkir (Dinatha \& Sutama, 2018). Penelitian serupa lainnya tentang perlindungan hukum terhadap konsumen atas pencantuman klausula baku dalam jasa parkir, menemukan bahwa pelaksanaan perlindungan hukum terhadap konsumen penggunea jasa parkir PT X di Kota Manado memberikan perlindungan hukum preventif berupa. Namun, belum efektif, sehingga perlindungan hukum represif menjadi alternatif terakhir konsumen untuk mendapatkan perlindungan hukum yaitu upaya penyelesaian sengketa melalui pengadilan (Makakombo, 2018). Dan terakhir tentang

perlindungan hukum terhadap konsumen jasa parkir dalam hal terjadinya kehilangan helm dan kendaraan bermotor di pasar Kereneng Denpasar, memaparkan bahwa bentuk perlindungan hukum pada konsumen jasa parkir di Pasar Kereneng Denpasar adalah perlindungan hukum represif, yang dilakukan dengan menerapkan Perda Kota Denpasar Nomor 11 Tahun 2005 tentang Sistem Penyelenggaraan Perparkiran dalam bentuk pemberian ganti rugi setengah dari kerugian yang dialami konsumen (Wiguna, Windari, \& Adnyani, 2018).

Permasalahan yang dikaji pada penelitian sekarang ini dirumuskan dengan Bagaimanakah Penerapan Peraturan Daerah Nomor 11 Tahun 2005 Tentang Sistem Penyelenggaraan Perparkiran di Kota Denpasar? Dan bagaimanakah Upaya Perusahaan Daerah Parkir Dalam Melindungi Konsumen Pengguna Jasa Parkir Terkait Kehilangan Yang Terjadi Di Area Parkir Lapangan Renon Denpasar? Sehingga penelitian ini bertujuan untuk mengetahui Penerapan Peraturan Daerah Nomor 11 tahun 2005 tentang Sistem Penyelenggaraan Perparkiran di Kota Denpasar dan upaya Perusahaan Daerah Parkir Kota Denpasar dalam melindungi pengguna jasa parkir terkat kehilangan di area parkir Lapangan Renon Denpasar.

\section{METODE PENELITIAN}


Dalam penelitian ini, metode yang digunakan adalah yuridis empiris dengan pendekatan sosiologis hukum. Metode pengumpulan data yang digunakan dalam penelitian ini adalah metode wawancara dan studi literatur. Wawancara dilakukan kepada Kepala Perusahaan Daerah Parkir dan petugas parkir yang bertugas di lapangan Renon. Sumber data dalam penelitian ini berupa data primer dan sekunder. Data primer diperoleh dari informan atau responden di lapangan, dalam penelitian ini yaitu konsumen atau pengguna jasa parkir dan tukang parkir yang ada di Lapangan Renon Kota Denpasar. Data sekunder adalah data yang bersumber dari kepustakaan, data sekunder dalam penelitian ini yaitu menggunakan kepustakaan.

\section{HASIL DAN PEMBAHASAN}

\section{Penerapan Peraturan Daerah Nomor 11 tahun 2005 tentang Sistem Penyelenggaraan Perparkiran di Kota Denpasar}

Tempat parkir kendaraan bermotor menjadi kebutuhan bagi pemilik kendaraan, karenanya parkir harus mendapat perhatian yang serius, terutama mengenai pengaturannya (Basri, 2015). Teori Lawrence Meir Friedman tentang Efektivitas Hukum memiliki 3 unsur sistem hukum untuk dijadikan patokan dalam mengukur keefektifan suatu peraturan.

1. Substansi Hukum (Substance of the Law)

Merupakan aturan, norma dan perilaku nyata manusia yang dibuat melalui peristiwa yang terjadi lebih dulu mencakup hukum yang hidup.

2. Struktur Hukum (Legal Structure)

Sistem hukum permanen untuk menjaga prosesnya agar tetap pada batasnya. Berdasarkan hasil wawancara yang dilakukan dengan Desak Made Eka Prastiawati (Kasi Pelaporan dan Pengaduan) Perusahaan Daerah Parkir terhadap Sistem Penyelenggaraan Perparkiran secara keseluruhan sudah berjalan dengan efektif. Namun ada beberapa yang belum efektif salah satunya masih terdapat tarif parkir yang tidak sesuai ketentuan. Pada Pelayanan Parkir Di Tepi Jalan Umum menyebutkan besaran biaya terhadap pelayanan pengguna parkir dikenakan retribusi sebagai berikut:
a. Truck
15.000
b. Bus besar/ Truck besar
10.000
c. Bus sedang/ Truck sedang
5.000
d. Sedan, Jeep, Minibus, Pickup, dan sejenisnya
2.000
e. Sepada Motor
1.000

Pengelolaan retribusi atau pemungutan tempat parkir ditepi jalan umum seharusnya dipungut sesuai dengan ketentuan dan besaran yang telah diatur dalam peraturan daerah tentang retribusi pelayanan parkir ditepi jalan umum. Didalam penyelenggaraan sistem perparkiran menunjuk petugas parkir atau juru parkir yang bertugas untuk mengatur, mengawasi, menertibkan dan memungut retribusi parkir kendaraan bermotor yang parkir ditempat yang ditentukan. Namun dalam pelaksanaannya petugas parkir banyak melakukan pemungutan pada area yang ada larangan parkir yang seharusnya tidak dikenakan biaya parkir dan kurangnya pengawasan dalam pemungutan retribusi parkir pada tempat yang ada larangan parkir. Petugas parkir atau juru parkir belum menjalankan tugasnya secara maksimal dalam melayani konsumen atau pengguna jasa parkir, petugas hanya meminta pungutan biaya sehingga melanggar peraturan perundang- undangan yang sudah ditentukan.

Berdasarkan penelitian yang dilakukan di Perusahaan Daerah Parkir didapatkan data kehilangan kendaraan bermotor pada tahun 2017 sebanyak 10 kasus, 2018 sebanyak 8 kasus, data pada tahun 2019 sebanyak 10 kasus. Data kehilangan yang bukan kendaraan bermotor (utuh) pada bulan Desember tahun 2019 sebanyak 18 kasus, dan pada bulan Januari tahun 2020 sebanyak 10 kasus. Dari uraian diatas dapat disimpulkan bahwa kasus kehilangan paling banyak terjadi bukan pada kehilangan kendaraan bermotor (utuh) melainkan pada bagian dari kendaraan seperti spion, atribut kendaraan contohnya helm dan barang lain seperti alat bantu dengar, alat penghubung jarak jauh yang diletakan di sadel motor.

\section{Upaya Perusahaan Daerah Parkir Kota Denpasar dalam Melindungi Pengguna Jasa Parkir Terkat Kehilangan di Area Parkir Lapangan Renon Denpasar}


Kebanyakkan bentuk tanggung jawab yang dilakukan oleh pengelola parkir adalah mengganti barang yang dititipkan (Putra, 2017). Dari hasil wawancara yang penulis laksanakan pada hari jumat tanggal 13 Maret 2020 pukul 08.30 waktu Indonesia tengah, kepada Desak Made Eka Prastiawati (Kasi Pelaporan dan Pengaduan). Dari penjelasan yang penulis terima, adapun upaya yang dilakukan dalam menyelesaikan kasus kehilangan bermotor (utuh) yaitu dengan memberikan santunan kepada korban, untuk mendapatkan klaim ganti rugi atas kehilangan kendaraan bermotor diperlukan beberapa syarat:

1) Berita acara kejadian dari Perusahaan Daerah Parkir

2) Surat keterangan hilang dari kepolisian setempat

3) Surat blokir kendaraan bermotor dari Polisi Daerah setempat

4) Buku Pemilik Kendaraan Bermotor dan Surat Tanda Nomor Kendaraan

5) Bukti karcis parkir yang asli

6) Photo copy Kartu Tanda Penduduk pemohon

7) Kunci kontak kendaraan yang hilang

8) Laporan kehilangan diterima paling lambat $3 \times 24$ jam dari saat terjadinya kehilangan

Klaim ganti rugi atas kehilangan kendaraan bermotor dibayarkan selambat-lambatnya 7 (tujuh) hari kerja sejak berkas pengajuan klaim diterima oleh perusahaan daerah parkir. Namun untuk diluar kasus kehilangan kendaraan bermotor seperti kehilangan bagian dari kendaraan bermotor, atribut berkendara dan lainnya merupakan diluar tanggung jawab dari Perusahaan Daerah Parkir. Dikatakan demikian karena hal tersebut termasuk kelalaian yang dilakukan oleh konsumen sendiri.

Adapun SOP penerimaan dan tindak lanjut laporan kehilangan atau klaim ganti rugi kehilangan dari Seksi pelaporan dan pengaduan menerima laporan kehilangan dari pelapor, lalu seksi pelaporan dan pengaduan mengecek semua kelengkapan syarat pengajuan klaim ganti rugi. (Apabila semua persyaratan lengkap maka proses pengajuan klaim akan dilanjutkan ke proses selanjutnya namun apabila syarat pengajuan klaim tidak lengkap maka proses klaim tidak dilanjutkan dan persyaratan di kembalikan kepada pelapor. Jika persyaratan pengajuan klaim ganti rugi lengkap, untuk selanjutnya seksi pelaporan dan pengaduan melakukan cross cek kelapangan atau ke lokasi tempat kejadian untuk mendapatkan informasi terkait terjadinya kehilangan tersebut. Setelah dilakukan cross cek ke lokasi kejadian dan informasi yang diperoleh memenuhi syarat untuk dilakukan klaim, maka untuk selanjutnya akan dibuat berita acara kehilangan. Berita acara tersebut terdiri dari dua yaitu berita acara tentang pemeriksaan kehilangan kendaraan di lokasi kejadian dan berita acara tentang kehilangan kendaraan. Setelah kedua berita acara lengkap, maka untuk selanjutnya seksi pelaporan dan pengaduan melaporkan ke pimpinan melalui Kepala bagian Tata Usaha, Direktur, Direktur Utama untuk diketahui dan mendapat Acc untuk pembayaran klaim tersebut. Setelah mendapat ACC dari pimpinan, maka untuk selanjutnya terkait proses pembayaran klaim ganti rugi tersebut ditangani Kepala seksi Operasional melalui seksi pengamanan dan pelayanan parkir untuk melakukan pemblokiran dan untuk selanjutnya pembayaran dilakukan oleh bagian keuangan.

Upaya yang dilakukan Perusahaan Daerah Parkir agar mengurangi terjadi kehilangan adalah sebagai berikut:

1. Mengadakan evaluasi setiap tahunnya

2. Mengarahkan petugas parkir untuk meningkatkan pelayanan keamanan, kenyamanan dan pengawasan terhadap kendaraan dari konsumen

3. Mengadakan pelatihan juru parkir setiap tahun

\section{SIMPULAN DAN SARAN}

\section{Simpulan}

Penerapan Peraturan Daerah Nomor 11 Tahun 2005 Tentang Sistem Penyelenggaraan Parkir secara keseluruhan belum berjalan efektif, karena masih terdapat tarif parkir yang tidak sesuai ketentuan, masih juga terdapat petugas parkir yang melakukan pemungutan parkir pada area yang ada larangan parkir dan masih ada petugas parkir atau juru parkir yang tidak mau melayani hanya meminta uang kepada konsumen.

Upaya yang dilakukan Perusahaan Daerah Parkir untuk mengurangi kasus kehilangan pada konsumen yaitu mengadakan evaluasi setiap tahun, meningkatkan pelayanan keamanan, kenyamanan terhadap kendaraan dari konsumen, mengadakan pelatihan juru parkir setiap tahun dan mengimbau 
konsumen parkir untuk ikut serta menjaga barang bawaannya. SOP penerimaan dan tindak lanjut laporan kehilangan atau klaim ganti rugi kehilangan dari penerimaan laporan lalu dilanjutkan mengecek kelengkapan, mengecek lokasi kejadian, pembuatan berita acara, jika semuanya sudah lengkap selanjutnya seksi pelaporan dan pengaduan melaporkan ke pimpinan melalui Kepala bagian Tata Usaha, Direktur, Direktur Utama untuk diketahui dan mendapatkan Acc untuk pembayaran klaim tersebut. Setelah di setujui, untuk proses pembayaran klaim ganti rugi tersebut ditangani Kasi Operasional.

\section{Saran}

Sehubungan dengan keefektivitasan Peraturan Daerah Nomor 11 Tahun 2005 Tentang Sistem Penyelenggaraan Parkir dan upaya mengurangi kasus kehilangan saran-saran yang dapat diberikan adalah:

1. Pada Perusahaan Daerah Parkir, disarankan untuk meningkatkan kembali pengawasan kepada petugas parkir yang sedang bertugas.

2. Pada orang yang kehilangan baik bukan kendaraan bermotor (utuh), misalnya kehilangan bagian dari kendaraan (spion), atribut kendaraan (helm), (headset, alat penghubung jarak jauh) sekiranya bisa diberikan santunan.

3. Bagi masyarakat atau konsumen parkir sekiranya ikut serta dalam menjaga barang bawaannya sendiri agar terhindar dari kasus kehilangan.

\section{DAFTAR PUSTAKA}

Basri. (2015). Perlindungan Hukum Terhadap Konsumen Parkir. Perspektif: Kajian Masalah Hukum Dan Pembangunan, 20(1). Retrieved from http://jurnalperspektif.org/index.php/perspektif/article/view/123

Budhiono, D. (2015). Tanggung Jawab Pelaku Usaha Jasa Perparkiran Bagi Konsumen Korban Pencurian Kendaraan Bermotor Di Kawasan Perbelanjaan Kota Manado. Lex Et Societatis, 3(8). Retrieved from https://ejournal.unsrat.ac.id/index.php/lexetsocietatis/article/view/9523

Dinatha, I. K. G. A., \& Sutama, I. B. P. (2018). Perlindungan Hukum Terhadap Konsumen Akibat Kehilangan Kendaraan Dalam Area Parkir (Studi Kasus Pasar Umum Desa Pakraman Sukawati). Kertha Semaya, 4(3). Retrieved from http://garuda.ristekbrin.go.id/documents/detail/1335200

Handayani, S. (2012). Aspek Hukum Perlindungan Konsumen Dalam Pelayanan Air Bersih Pada PDAM Tirtasari Binjai. Jurnal Non Eksata, 4(1).

Makakombo, V. (2018). Perlindungan Hukum Terhadap Konsumen Atas Pencantuman Klausula Baku Dalam Jasa Parkir (Universitas Brawijaya). Retrieved from http://repository.ub.ac.id/171329/

Putra, H. S. (2017). Perjanjian Baku Yang Terdapat Dalam Karcis Pengelola Parkir Dan Pertanggung Jawaban Pengelola Parkir Terhadap Barang Milik Konsumen. Surya Keadilan: Jurnal Ilmiah Nasional Terbitan Berkala, 1(1). http://jurnal.umb.ac.id/index.php/suryakeadilan/article/view/86

Wiguna, I. B. W. P., Windari, R. A., \& Adnyani, N. K. S. (2018). Perlindungan Hukum Terhadap Konsumen Jasa Parkir Dalam Hal Terjadinya Kehilangan Helm Dan Kendaraan Bermotor Di Pasar Kereneng Denpasar. Jurnal Komunitas Yustina, 1(2). Retrieved from https://ejournal.undiksha.ac.id/index.php/jatayu/article/view/23795

Yanto, E., Imawanto, \& Yuliani, T. (2020). Perlindungan Hukum Konsumen Jasa Parkir Ditinjau Dari Hukum Positif. Media Keadilan: Jurnal Ilmu Hukum, 11(1). Retrieved from https://journal.ummat.ac.id/index.php/JMK/article/view/2264

http://www.galeripustaka.com/2013/05/pengertian-cara-dan-jenis-parkir.html?m=1. Diakses pada 19 oktober 2019 pukul 19.00 .

https://pdparkir.denpasarkota.go.id/page/read/498. Diakses pada 23 Februari 2020 pukul 15.00.

Peraturan Daerah Denpasar Nomor 5 Tahun 203 Tentang Perusahaan Daerah Parkir Kota Denpasar Peraturan Daerah Denpasar Nomor 11 Tahun 2005 Tentang Sistem Penyelenggaraan Perparkiran Peraturan Daerah Kota Denpasar 19 Tahun 2011 Tentang Retribusi Pelayanan Pakir Di Tepi Jalan Umum Peraturan Walikota Denpasar Nomor 30 Tahun 2006 Tentang Petunjuk Pelaksanaan Peraturan Daerah Kota Denpasar Nomor 11 Tahun 2005 Tentang Sistem Penyelenggaraan Perparkiran. 